\title{
ANALISIS DAN PERANCANGAN APLIKASI PERLINDUNGAN HAK CIPTA DAN OTENTIKASI DOKUMEN MENGGUNAKAN TEKNIK ANALISIS KRIPTOGRAFI
}

\author{
Erika Ramadhani' $^{1)}$, Wahluf Abidian ${ }^{2)}$ \\ Program Studi Informatika, Fakultas Teknologi Industri \\ Universitas Islam Indonesia \\ Yogyakarta, Indonesia \\ Corresponding Email: erika@uii.ac.id
}

\begin{abstract}
ABSTRAK
Internet merupakan teknologi komunikasi antar perangkat jaringan yang tersebar dan terbesar didunia saat ini. Setiap tahun pengguna Internet semakin bertambah. Penambahan pengguna Internet berbanding lurus dengan penambahan jumlah data di Internet. Penggunaan terhadap data dari Internet sangatlah mudah dan lebih rentan terhadap kebebasan dalam pengaksesannya. Akibatnya, setiap dokumen yang sudah masuk ke dunia Internet akan berubah menjadi dokumen yang bebas bisa digunakan oleh siapa saja. Berdasarkan pada permasalahan tersebut, maka penulis melakukan perancangan pembuatan sistem yang mampu memberikan perlindungan hak cipta sekaligus menjaga keaslian dari dokumen tersebut walaupun dokumen tersebut sudah memasuki dunia Internet. Proses perancangan sistem akan menggunakan metode design thinking yang menghasilkan sebuah rekomendasi berupa model UI/UX. Metode perancangan ini akan menggunakan target dari pengguna dengan melihat apa kebutuhan yang diperlukan oleh pengguna. Sedangkan teknik analisis kriptografi digunakan untuk menginterpretasikan bagaimana sistem akan bekerja.
\end{abstract}

Kata kunci/keywords: design thinking; hak cipta; teknik kriptografi; aplikasi handphone; otentikasi.

\section{Pendahuluan}

Data adalah sumber alam yang baru, melalui sumber daya alam yang baru ini kita memiliki peluang bernilai tinggi melalui pengolahan data (Dahono, 2014). Pada tahun 2020 diperkirakan 1,7 megabyte informasi baru akan dibuat setiap detik untuk seorang pengguna internet. Sekitar 1/3 dari data tersebut akan masuk ke dalam komputasi awan (Wassen, 2018). Secara total jumlah data yang ada di alam semesta digital ini berjumlah 2,7 zettabytes. Nilai 1 zettabytes setara dengan $1 \mathrm{e}+12$ atau 1.000.000.000.000 gigabyte.

Pengamanan informasi yang bersifat pribadi sangat diperlukan, terutama pada informasi yang akan dipublikasikan di Internet. Citra merupakan salah satu informasi yang banyak disalahgunakan. Gambar atau citra digital dapat dilindungi dengan melakukan menyisipkan sebuah identitas pada gambar dengan hasil yang tidak merubah gambar aslinya. Teknik image watermarking merupakan salah satu teknik yang dapat digunakan untuk melindungi hak cipta dari sebuah citra digital atau gambar. Untuk menjaga keaslian data selama berada di jaringan Internet, maka citra tersebut diberikan sebuah tanda tangan digital.

Perlindungan hak cipta terhadap sebuah citra digital diperlukan dua kriteria sehingga layak untuk dilakukan perlindungan. Kriteria pertama adalah citra gambar yang dibuat merupakan hasil orisinil yang dibuat oleh si pembuat. Citra gambar tersebut memiliki ciri khas tertentu yang merujuk kepada kreativitas seseorang. Kemudian, gambar tersebut merupakan sebuah citra yang berasal dari media digital atau film yang tidak etis untuk dijadikan ide atau konsep fotografi.

Untuk mengatasi permasalahan tersebut, maka pada makalah ini menawarkan sebuah solusi berupa aplikasi berbasis perangkat bergerak untuk membuat hak cipta pada sebuah citra digital atau gambar. Pada aplikasi ini memiliki beberapa fitur seperti pembuatan hak cipta dan pemeriksaan hak 
cipta pada sebuah citra digital atau gambar. Teknik yang digunakan adalah teknik watermark dan tandatangan digital.

Tahap awal proses pembuatan aplikasi adalah melakukan analisis dan perancangan sistem. Proses analisis dan perancangan mengikuti kaidah dari pemikiran desain (design thinking). Sehingga keluaran dari makalah ini berupa hasil analisis dan perancangan UI/UX aplikasi berbasis perangkat bergerak. Proses kerja dari sistem yang dibuat berdasarkan pada teknik kriptografi. Sistem yang akan dibuat mampu mengamankan sekaligus menjaga keaslian data citra tersebut.

\section{Kajian Pustaka}

Aplikasi perangkat bergerak merupakan aplikasi yang dirancang untuk memudahkan aktivitas pengguna menjadi lebih fleksibel. Aplikasi perangkat bergerak terdiri dari tiga jenis: aplikasi native, aplikasi mobile web, dan aplikasi hybrid. Aplikasi native biasanya khusus dikembangkan pada salah satu platform saja. Misalnya jika ingin membuat aplikasi dengan basis sistem operasi Android. Selanjutnya aplikasi mobile berbasis web merupakan aplikasi web yang bisa diakses melalui web mobile tanpa terbatas pada sistem operasi yang digunakan. Untuk aplikasi hybrid, ini merupakan gabungan dari native dengan web aplikasi. Biasanya model hybrid ini digunakan pada saat ingin menambah fitur-fitur tertentu tetapi berbasis kepada perangkat bergerak.

User experience (UX) merupakan istilah yang sering digunakan di kalangan pengembang aplikasi. UX adalah bagaimana seorang pengguna aplikasi dalam mengakses atau menggunakan aplikasi tersebut dan pengalaman apa yang didapatkan dalam mengakses aplikasi tersebut. Contoh dari UX adalah fitur-fitur yang ada pada sebuah aplikasi, tampilan, prosedur dan sebagainya. UX juga biasa disebut sebagai pengalaman pengguna. Sedangkan bagian yang berinteraksi langsung dengan pengguna biasanya disebut dengan user interface (UI).

Teknik watermark dan tandatangan digital merupakan dua teknik yang bisa diintegrasikan untuk menjaga keaslian sebuah data dan melindungi hak cipta suatu data. Biasanya watermark diimplementasikan pada perlindungan hak cipta suatu gambar. Kemudian teknik tandatangan digital juga merupakan salah satu contoh untuk perlindungan hak cipta. Teknik kriptogragi digunakan untuk menjaga keaslian data pada saat data tersebut dikirimkan dan dipublikasi dijaringan internet.

\section{Metode Perancangan}

\subsection{Pemikiran Desain}

Pendekatan pemikiran desain merupakan salah satu pendekatan dalam memecahkan sebuah masalah. Masalah yang dipecahkan disini adalah bagaimana merancang sebuah prototipe aplikasi perlindungan hak cipta dan otentikasi citra digital yang memiliki inovasi lebih bila dibandingkan dengan aplikasi yang sudah ada. Terkait dengan makalah ini, pendekatan pemikiran desain dipilih karena pendekatan ini merupakan metode penyelesaian masalah yang terpusat kepada kebutuhan pengguna. Selain itu juga berfokus kepada kreativitas yang sifatnya lebih inovatif.

Lima tahap dalam pemikiran desain adalah berempati, mendefinisikan masalah, eksplorasi ide, membuat prototipe, dan pengujian. Setiap tahapan tersebut dibuat berdasarkan kepada kebutuhan pengguna.

1. Empati: merupakan tahapan awal yang merupakan inti dari keseluruhan tahapan. Pada tahapan ini dilakukan proses wawancara, observasi, tanya jawab dengan menggunakan skenario tertentu. Tujuan pada tahapan ini adalah untuk menggali apa yang menjadi permasalahan dari pengguna dan apa yang diinginkan oleh pengguna untuk pengembangan sistem kedepannya. Berdasarkan pada tahapan ini, akan ada masalah dan solusi yang didapatkan. Yang menyebabkan tahapan ini menjadi kreatif dan inovatif adalah karena setiap tahapan yang nanti akan dilewati pada pemikiran desain ini bersifat berkesinambungan dan berkelanjutan. 
2. Definisi Masalah: merupakan tahapan yang mengelaborasi hasil dari tahap awal. Pada tahap ini, sudah menentukan titik permasalahan yang dihadapi berdasarkan pada wawasan yang didapatkan pada proses empati. Penetapan masalah sudah didapatkan pada tahapan ini.

3. Eksplorasi Ide: merupakan tahapan penentuan solusi terhadap permasalahan yang didapat pada tahap sebelumnya. Solusi ini nanti akan dijadikan pegangan dalam pengembangan sistem yang akan dibuat.

4. Prototipe: setelah melewati ketiga tahap sebelumnya, maka pada tahapan ini mulai dilakukan perancangan prototipe terhadap sistem yang akan dibuat.

5. Pengujian: tahapan ini melakukan pengujian terhadap prototipe yang sudah dibuat. Pengujian diberikan kepada seorang pengguna. Pada prosesnya, kemungkinan perbaikan pada tahapantahapan sebelumnya bisa saja terjadi.

\subsection{Teknik Kriptografi}

Teknik kriptografi merupakan suatu teknik mengamankan sebuah data, selain itu teknik ini juga digunakan untuk menjaga keaslian sebuah data. Pada teknik ini dikenal dua istilah penting, yakni enkripsi dan dekripsi. Enkripsi merupakan teknik untuk membungkus data dengan menggunakan metode tertentu sehingga data tersebut menjadi aman apabila dilakukan proses pengiriman data menuju jaringan Internet. Sedangkan dekripsi merupakan teknik yang digunakan untuk membuka data yang sudah di enkripsi.

\subsection{Proses Bisnis Sistem}

Proses bisnis dari aplikasi ini merupakan alir kerja dari sistem. Pengguna pada sistem ini merupakan satu pengguna yang ingin melakukan perlindungan hak cipta terhadap citra digital yang dimiliki. Kemudian satu pengguna yang ingin keaslian datanya selalu terjamin dan terjaga pada saat data tersebut dikirimkan melalui jaringan Internet. Sehingga proses bisnis dari aplikasi ini memiliki alur seperti Gambar 1 berikut:

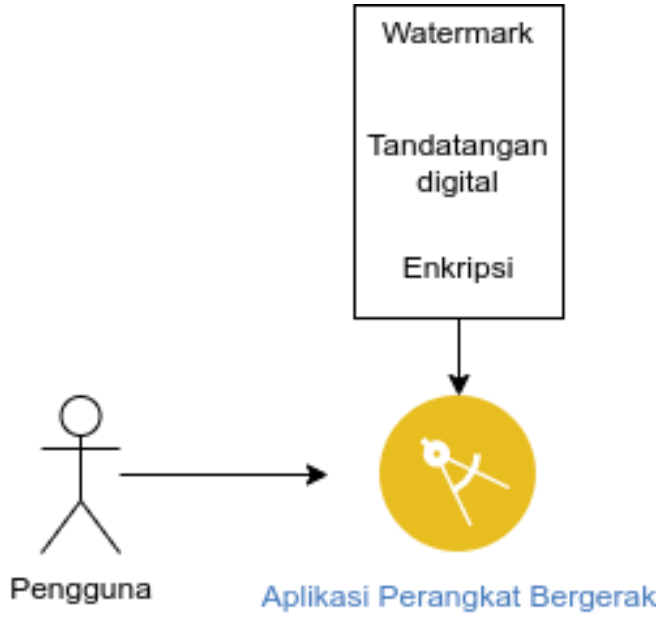

Gambar 1. Proses Bisnis Sistem

Teknik watermark yang digunakan adalah teknik domain frekuensi yakni discrete wavelet transformation (DWT). Kemudian teknik tandatangan yang digunakan adalah teknik Elliptic Curve Digital Signature Algirthm (ECDSA). Alur kerja sistem menggunakan teknik kriptografi. 


\section{Hasil dan Pembahasan}

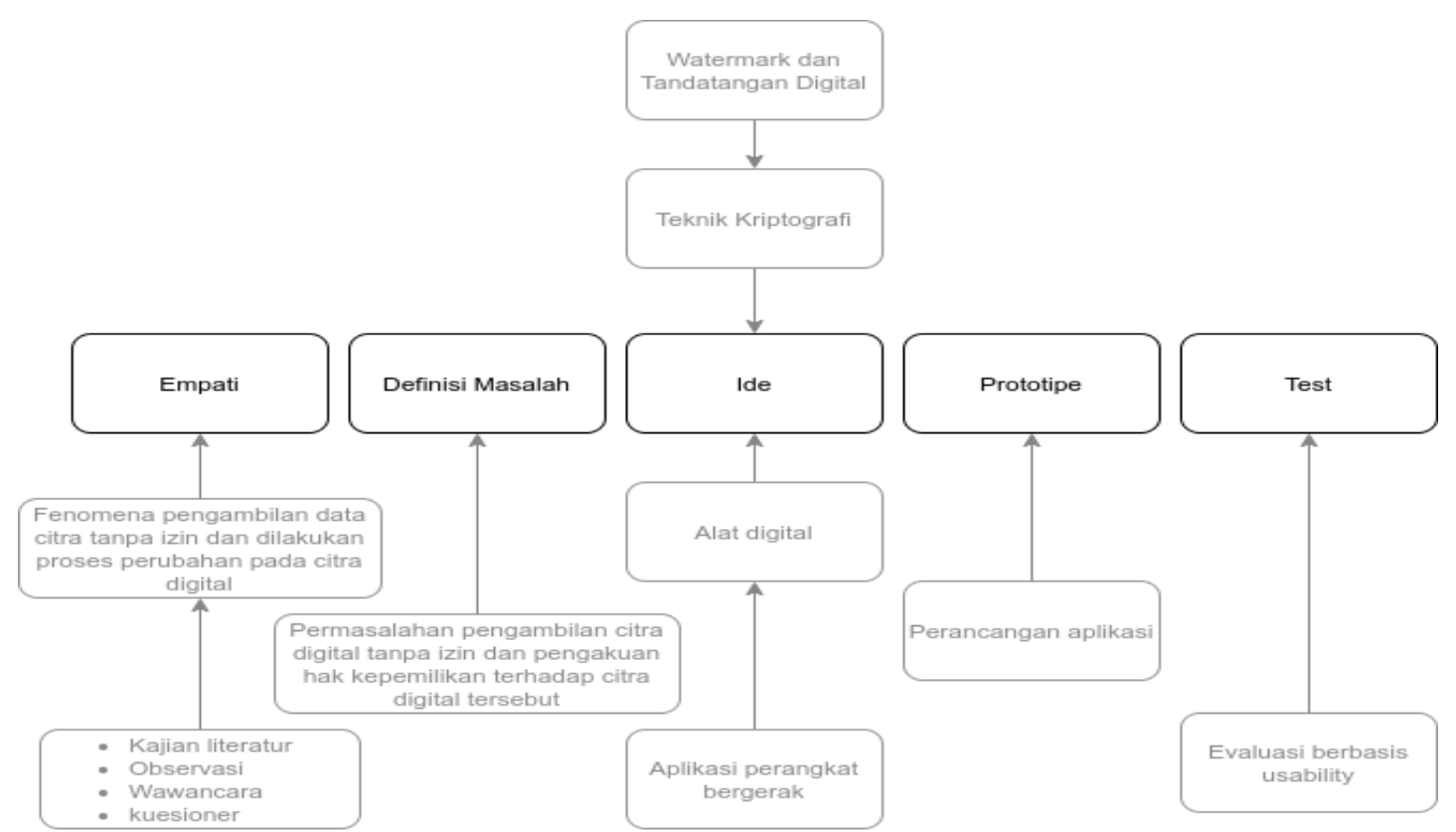

Gambar 2. Diagram Hubung Teori Pemikiran Desain dalam Metode Perancangan

Gambar 2 merupakan paparan kerangka alur metode yang didapatkan pada saat melakukan perancangan dalam mengatasi masalah pada penelitian ini.

1. Empati.

Tahapan ini dilakukan penyebaran kuesioner terhadap calon pengguna. Hal ini ditujukan untuk mendapatkan pandangan terhadap kebutuhan dari sistem yang akan dibuat. Selanjutnya dilakukan observasi untuk melihat aplikasi yang sudah ada saat ini, kemudian digunakan sebagai bahan literatur untuk kajian dan perbandingan.

2. Definisi Masalah

Tahapan ini dilakukan penentuan masalah dari sistem yang akan dibuat. Definisi masalah dituliskan dalam bentuk pertanyaan yakni bagaimana melakukan analisis dan perancangan sistem yang bertujuan untuk melindungi hak cipta citra digital dan mengamankan keaslian dari citra digital tersebut.

3. Penggalian Ide

Tahapan ini merupakan hasil dari dua tahapan sebelumnya, ide yang didapatkan adalah membangun sistem berupa aplikasi berbasis perangkat bergerak yang digunakan pada sistem operasi Android. Aplikasi akan memberikan fitur watermark dan tandatangan digital untuk memberikan perlindungan hak cipta dan mengamankan data citra digital apabila dipublikasi ke jaringan Internet. Untuk menjaga keaslian dari citra digital, maka akan dibuat aplikasi yang merujuk kepada teknik kriptografi.

4. Prototipe

Setelah melewati tahapan empati, definisi masalah, dan penggalian ide. Maka masuklah ke tahapan pembuatan prototipe. Pada pembuatan prototipe ini dibagi menjadi tiga bagian pembahasan. Tiga bagian tersebut adalah alur kerja pengguna, alur kerja aplikasi, dan mockup aplikasi. 


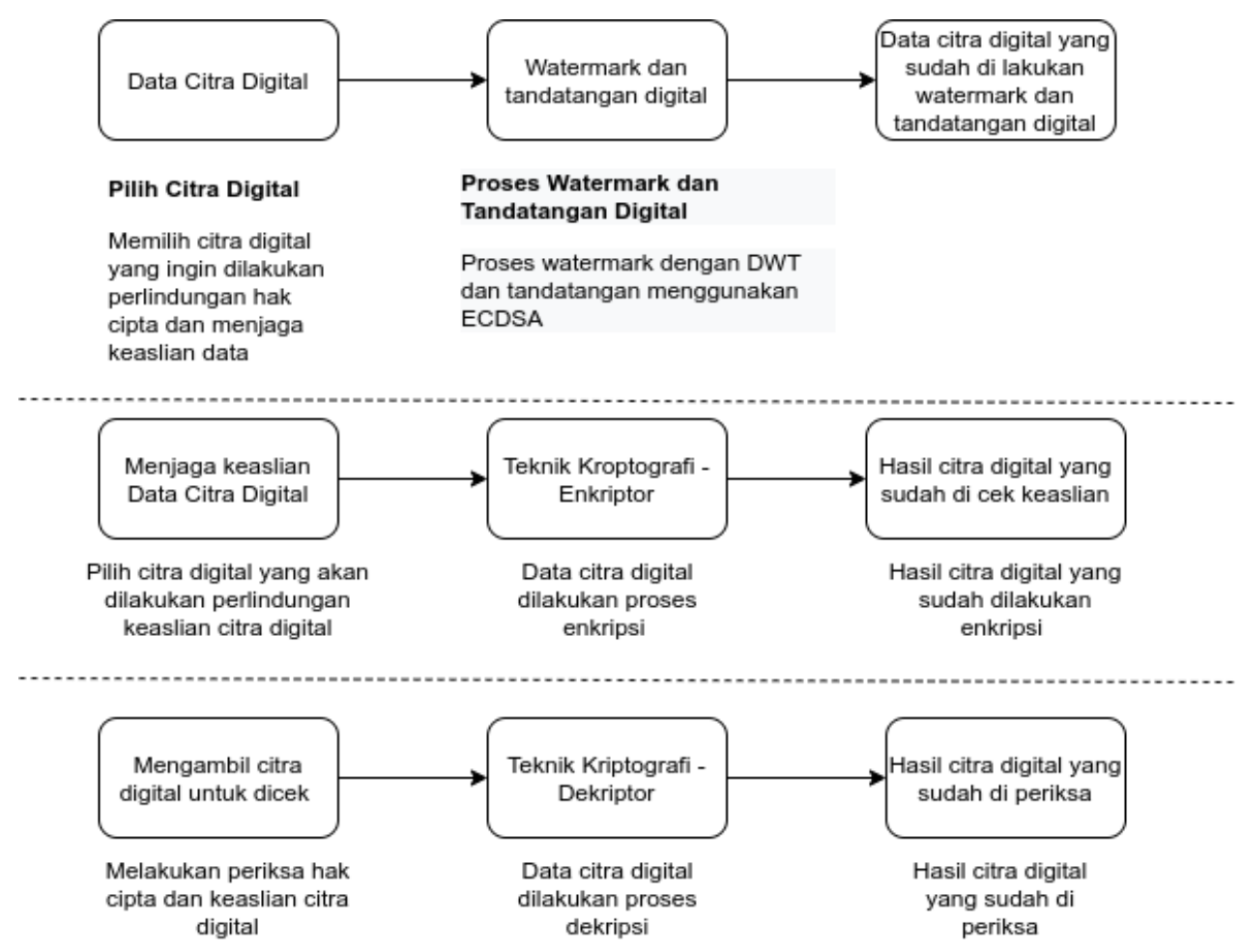

Gambar 3. Alur Kerja Pengguna

Gambar 3 merupakan alur kerja dari pengguna yang akan memakai aplikasi perlindungan hak cipta. Pada bagian alur pengguna dibagi menjadi tiga bagian, yakni proses secara keseluruhan, proses menjaga keaslian data, dan proses pengecekan terkait perlindungan hak cipta.

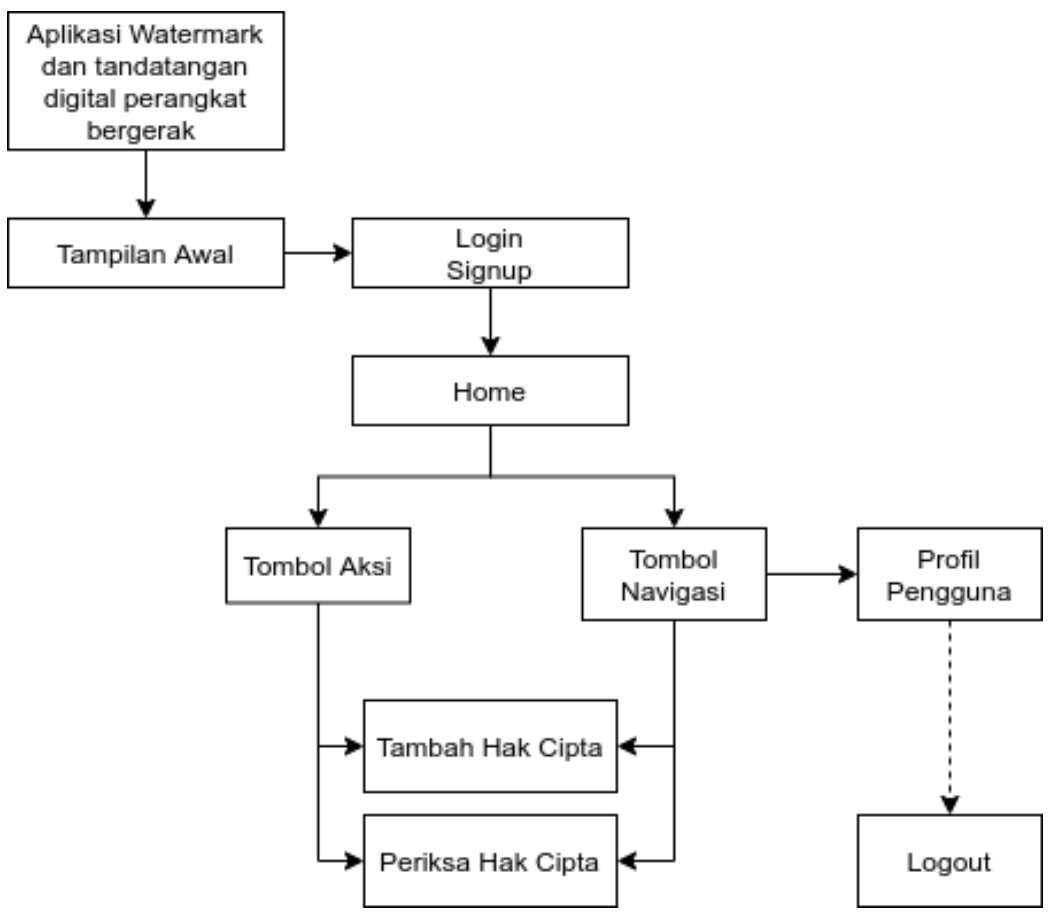

Gambar 4. Alur Kerja Aplikasi

Alur kerja aplikasi ditunjukkan pada Gambar 4, pada saat aplikasi pertama kali dibuka maka akan menampilkan tampilan menuju halaman login atau signup. Setelah melakukan login maka user akan ditunjukkan ke halaman home. Pada halaman home terdapat dua tombol navigasi dan tombol 
aksi. Tombol navigasi dan tombol aksi keduanya melakukan aksi terhadap proses tambah hak cipta dan periksa hak cipta. Pada tombol navigasi, pengguna bisa memilih profil pengguna dan melakukan logout aplikasi.

Gambar 5 memberikan tampilan halaman login bagi pengguna. Seluruh pengguna aplikasi harus melakukan pendaftaran akun terlebih dahulu sebelum menggunakan aplikasi ini. Pendaftaran akun digunakan sebagai tempat untuk menyimpan riwayat dari pengguna ketika melakukan penambahan hak cipta. Riwayat digunakan untuk melihat kembali daftar gambar apa saja yang telah diberi hak cipta.
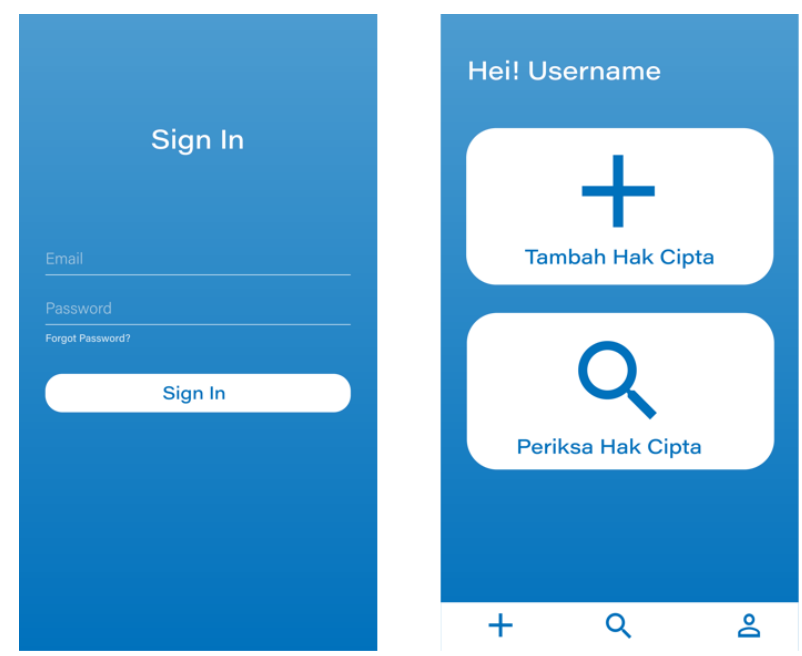

Gambar 5. (a) Tampilan Login (b) Tampilan Home

Gambar 6 memberikan tampilan halaman home pengguna. Seluruh pengguna dapat menggunakan dua fitur yang berbeda sesuai dengan kebutuhan pengguna. Pada "Tambah Hak Cipta" adalah fitur yang digunakan untuk memasang Hak Cipta pada gambar pengguna. Sedangkan pada "Periksa Hak Cipta" adalah fitur yang digunakan untuk melakukan pengecekan gambar terkait hak cipta yang ada didalamnya. Pada bagian bottom navigation terdapat 3 pilihan navigasi yang akan mengarahkan pengguna kepada bagian tambah hak cipta, periksa hak cipta, dan profil pengguna.

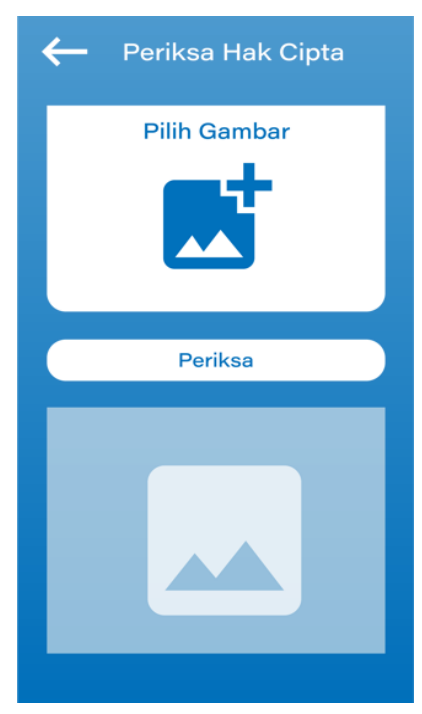

Gambar 6: Halaman Periksa Hak Cipta

Gambar 6 memberikan tampilan halaman periksa hak cipta. Halaman ini menampilkan "Pilih Gambar" yang akan digunakan untuk memilih gambar dan button "Periksa". Setelah gambar yang akan dicek hak ciptanya dipilih kemudian button periksa ditekan maka hasil dari watermark gambar 
tersebut akan muncul dibawah button "periksa". Apabila hak cipta tidak ditemukan maka akan muncul notifikasi "Tidak ada Hak Cipta" melalui sebuah toast.

Gambar 7 memberikan tampilan halaman tambah hak cipta. Pada bagian ini pengguna perlu memasukkan gambar asli dan juga gambar sebagai hak cipta. Terdapat pula ketentuan untuk gambar yang akan digunakan sebagai watermark untuk hak cipta. Setelah gambar dipilih, dengan ditekannya button "Buat Hak Cipta" maka proses pembuatan hak cipta pada gambar akan dilakukan. Hasil dari proses tersebut akan muncul pada sesuai dengan title "Hasil gambar dengan hak cipta". Setelah gambar selesai diproses pengguna dapat melakukan reset proses melalui button "Reset Proses" untuk mengulang proses dan terdapat button "Unduh Gambar" untuk menyimpan gambar.

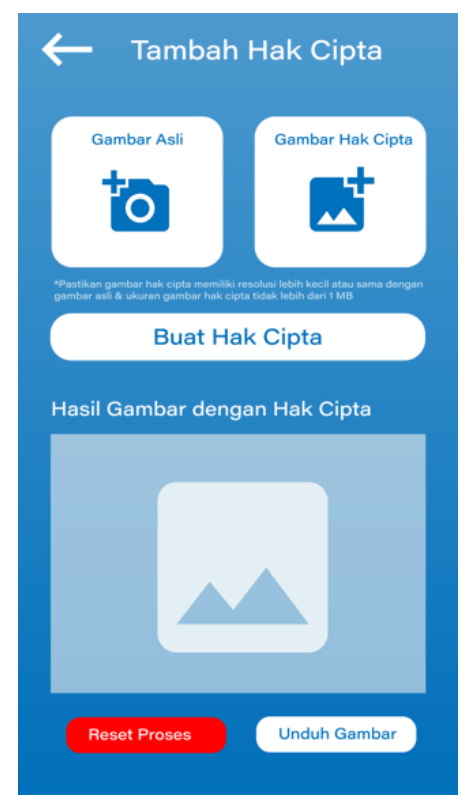

Gambar 7: Tampilan Periksa Hak Cipta

\section{Testing}

Pada proses tahapan akhir ini dilakukan pengujian terhadap prototipe yang sudah dibuat. Prototipe diujikan kepada responden dengan diberikan kuesioner untuk dijawab. Masukan dan saran didapat dari tahap ini adalah pengguna membutuhkan bantuan orang lain atau teknisi pada saat menggunakan sistem. Secara keseluruhan pengguna menganggap aplikasi ini sangat bermanfaat dan sesuai dengan kebutuhan mereka, tetapi ada beberapa bagian perlu dilakukan perbaikan dan diberikan masukan.

\section{Kesimpulan}

Proses analisis dan perancangan sebuah sistem sangat penting dilakukan. Penelitian ini membuat sebuah aplikasi berbasis perangkat bergerak untuk memberikan perlindungan hak cipta dan menjaga keaslian citra digital apabila sudah memasukin jaringan Internet. Metode yang digunakan pada proses watermark adalah metode DWT dan metode ECDSA pada teknik tandatangan digital. Kemudian untuk melindungi keaslian dari citra digital digunakan teknik kriptografi. Keseluruhan proses analisis dan perancangan dilakukan dengan pendekatan pemikiran desain. Langkah-langkah yang dilalui pada pendekatan pemikiran desain adalah empati, definisi masalah, penggalian ide, prototipe, dan testing. Hasil pengujian menunjukkan bahwa aplikasi sangat bermanfaat untuk menjaga hak cipta dan menjaga hak cipta sebuah citra digital. 


\section{Daftar Pustaka}

Wassen, O. (2018, 10 26). nodegraph. (nodegraph) Dipetik 04 22, 2020, dari https://www.nodegraph.se/big-data-facts/

Dahono, Y. (2014, Oktober 14). IBM : Data Adalah Sumber Daya Alam Baru. (berita satu) Dipetik 04 22, 2020, dari Berita Satu: beritasatu.com/iptek/217314-ibm-data-adalah-sumber-dayaalam-baru

Muadzani, A., Nurhayati, O. D., \& Widangsari, I. P. (2016). Penyisipan Media Teks dan Citra Menggunakan Teknik Steganografi pada Media Pembawa Citra Digital. Jurnal Teknologi dan Sistem Komputer.

Amalina , S., Wahid, F., Satriadi, V., Farhani, F. S., \& Setiani, N. (2017). Rancang Purwarupa Aplikasi UniBook Menggunakan Metode Pendekatan Design Thinking. Seminar Nasional Aplikasi Teknologi Informasi 2017, E-50.

Ismanto , D., \& Wibowo, V. (2019). Rancang Bangun Watermarking Citra Digital Menggunakan Metode Discrete Cosine Transform Berbasis Android. Journal ENTER, 64-75.

Supangkat, S. H., Priyanto, K., \& Juanda. (2000). Watermarking Sebagai Teknik Penyembunyian Label Hak Cipta pada Data Digital. Teknik Elektro, 19-27. 